\title{
THE PRODUCTION OF SHEEP'S MILK IN EU COUNTRIES
}

\author{
Tomasz Rokicki ${ }^{1}$, PhD habil; Marcin Ratajczak ${ }^{2}, \mathrm{PhD}$; Magdalena Golonko ${ }^{3}$, PhD student
} $1,2,3$ Warsaw University of Life Sciences

\begin{abstract}
The main objective of the studies was to discuss situation in sheep milk market in the European Union. Specific objectives include presentation of the data related to dairy sheep's population and commercial production of sheep's milk in separate EU countries, as well as indication of the main interdependent factors with milk production. Studies have been performed on a group that included all the countries which belonged to the EU as of 31.12 .2013 and commercial produce a sheep's milk. There were 14 such countries. Data assumed for studies concerned years 20082017. The sources of materials were analysis of literature, EUROSTAT Database. For the purposes of the analysis of the materials, the authors used dynamic indicators on variable base, Gini coefficient, concentration analysis using the Lorenzo curve, and the Pearson linear correlation coefficient. For materials' presentation the authors used descriptive, tabular and graphical methods. Studies carried out allowed to show changes in sheep's milk production. In 2008-2017, the production of sheep's milk intended for processing in dairies increased, which could have been a result from the less internal consumption of farms. The level of concentration of sheep milk production in the EU was very high, but there were No changes in this regard. Commercial production of sheep's milk was concentred in several countries, like Greece, Spain, Italy and France. Commercial production of sheep's milk was more correlated with sheep population and lamb meat production, than population of dairy sheep and economy parameters.
\end{abstract}

Key words: EU countries, sheep production, sheep milk, dairy sheep population.

JEL code: F15, O11, Q10.

\section{Introduction}

Throughout the centuries, milk was a desirable and valuable food source wherever livestock animals were bred (Barlowska et al., 2011). Sheep milk contains higher levels of total solids and major nutrient than cow and goat milk. Lipids in sheep milk have higher physical characteristics than in cow milk. Mineral and vitamin contents of sheep milk are mostly higher than in cow milk. The highest energy value is characteristic of sheep milk, too (Park et al., 2007). Sheep milk is the richest in whey proteins and also contains the highest concentration of casein (Dario et al., 2008). Milk is an important source of mineral substances, especially calcium, sodium, phosphorus, potassium, chloride, magnesium, iodine, and small amounts of iron. The highest concentration of this mineral elements is in sheep milk (Al-Wabel, 2008).

For the production and promotion of sheep milk and derivative dairy products very important are information on fatty acid (FA) profile. The presence of the essential $\omega-3$ and $\omega-6$ FA in milk fat as well as other less common FA, like linoleic acid isomers, has gained an increasing interest due to the consumer demand for a healthy diet (Sinanoglou et al., 2015). Characteristic of sheep milk is a higher concentration of conjugated linoleic acid (CLA) than cow and goat milk (Talpur et al., 2008). The aforementioned CLA has numerous functional properties. It is claimed to inhibit the occurrence and development of cancer of the skin, breast, colon, and stomach (Parodi, 1999), prevent obesity (Bawa, 2003; Wang and Jones, 2004). Additionally, CLA reduces the levels of triglycerides, total cholesterol, including LDL, and thus improves the ratio of LDL/HDL in plasma, therefore, it prevents coronary heart disease and atherosclerosis (GaviNo et al., 2000; Tricon et al., 2004). CLA also is said to inhibit the development of osteoporosis (Watkins and Seifert, 2000), to improve the metabolism of lipids, to reduce the blood glucose level, and to stimulate the immune system (O'Shea et al., 2004). For the above reasons, sheep's milk is a very valuable food source. Sheep milk, regarding their high content of protein, including casein, and fat, make a very good raw material for processing, especially cheese-making (de la Fuente et al., 2013).

Global milk production is dominated by five animal species: dairy cattle, buffalo, goats, sheep and camels. The annual production of sheep's milk in the world is about 10.5 million tons and constitutes $1.3 \%$ of the total milk production obtained from various mammalian species (Faostat, 2017). The most of 
production is used to manufacture cheeses and fermented beverages. Products from sheep milk are commonly considered as regional articles. They are protected by legal regulations which guarantee their taste and aroma typical for a given region and which they owe to traditional production technologies (Dankow and Pikul, 2011). The world's major producer of sheep milk was China (about $12 \%$ ). However, most sheep's milk is produced in EU countries. Milk is the EU number one single product sector in terms of value at approximately $15 \%$ of agricultural output. In 2016, the farms in the EU-28 produced approximately 168.3 million tons of milk. Production of cows' milk was 163.0 million tons ( $97 \%$ of all milks produced). Milk from ewes, goats and buffalos represented 5.4 million tons (3.1\%). The main part of milk produced was delivered to the dairies and the remaining amount (11.2 million tons) was used otherwise on the farms, i.e. own-consumed, processed, used as feed, or sold directly to consumers. The production of sheep's milk accounted for around 2.8 million tons, and 1.9 million tons went to the dairy. The leaders in Europe include Greece, Turkey, Romania and Italy. Almost all of the sheep milk produced is used for cheese-making, whether on the farm or in industrial dairies. Spain, Italy and France produced $93 \%$ of total EU production of cheese from ewe's pure milk (The sheep..., 2017; Milk.., 2017; Rokicki, 2017; Rokicki and Ratajczak, 2018).

\section{Materials and methods}

The purpose of the article was to discuss situation in sheep milk market in the European Union. In addition, the paper also presents specific objectives. Such objectives include: presentation of the data related dairy sheep's population and commercial production of sheep's milk in separate EU countries; as well as indication of the main interdependent factors with milk production. Studies have been performed on group included all the countries which belonged to the EU as of 31.12.2013 and commercial produce a sheep's milk. There were 14 such countries: Austria, Belgium, Bulgaria, Croatia, Cyprus, France, Greece, Hungary, Italy, Poland, Portugal, Romania, Slovakia, Spain. Data assumed for studies concerned years 2008-2017. The sources of materials were analysis of literature, EUROSTAT Database. The paper uses the following methods: descriptive, tabular, graphical, dynamic indicators on variable base, Gini coefficient, concentration analysis using the Lorenzo curve, and the Pearson linear correlation coefficient.

Two hypotheses were stated in the work.

1) In 2008-2017, the level of concentration of sheep milk production in the EU increased.

2) Commercial production of sheep's milk was more correlated with the population of dairy sheep than with other parameters related to sheep production.

The dynamics indicators based on a variable basis are defined as follows (Starzynska, 2002):

$$
i=\frac{y_{n}-y_{n-1}}{y_{n-1}} \text { or } i=\frac{y_{n}-y_{n-1}}{y_{n-1}} \cdot 100 \%
$$

where: $y_{n}$ - the level of the phenomenon in a certain period, $y_{n-1}$ - the level of the phenomenon in the previous period.

The Gini coefficient is a measure of the concentration (unevenness) of the distribution of a random variable. If the observations yi are ordered in ascending order, the coefficient can be saved with the formula (Dixon et al., 1987, Damgaard and Weiner, 2000):

$$
G(y)=\frac{\sum_{i=1}^{n}(2 i-n-1) * y_{i}}{n^{2} * \bar{y}}
$$

where: $\mathrm{n}$ - number of observations, 
where: $\mathrm{n}$ - number of observations

$$
\begin{aligned}
& y_{i} \text { - i-observation value, } \\
& \bar{y} \text { - average value of all observations, i.e. } \bar{y}=\frac{1}{n} \sum_{i=1}^{n} y_{i}
\end{aligned}
$$

The Lorenz curve determines the degree of concentration of a one-dimensional distribution of a random variable (Dagum, 1980). With sorted $\mathrm{y}_{\mathrm{i}}$ observations that take non-negative values $0 \leq y_{1} \leq y_{2} \leq \ldots \leq y_{n}$ , $\sum_{i=1}^{n} y_{i}>0$, the Lorenz curve is a polygonal chain, which vertices $\left(x_{h}, z_{h}\right)$, for $\mathrm{h}=0,1, \ldots, \mathrm{n}$ (fixed number), have coordinates

$$
x_{0}=z_{0}=0, \quad x_{h}=\frac{h}{n}, \quad z_{h}=\frac{\sum_{i=1}^{h} y_{i}}{\sum_{i=1}^{n} y_{i}}
$$

The Gini coefficient determines the area between the Lorenz curve and the diagonal of a unit square multiplied by 2 .

Pearson's linear correlation coefficient is a measure of the strength of a straight line relationship between two measurable features. It is expressed by the formula (Jajuga and Walesiak, 2004):

$$
r_{X Y}=\frac{C(X, Y)}{\sqrt{S_{X}{ }^{2} \cdot S_{Y}{ }^{2}}}=\frac{\sum_{i=1}^{n}\left(x_{i}-\bar{x}\right)\left(y_{i}-\bar{y}\right)}{\sqrt{\sum_{i=1}^{n}\left(x_{i}-\bar{x}\right)^{2} \cdot \sum_{i=1}^{n}\left(y_{i}-\bar{y}\right)^{2}}}=\frac{C(X, Y)}{S_{X} \cdot S_{Y}}
$$

where: $C(X, Y)$ - covariance between $X$ and $Y$ features,

$S_{X}{ }^{2}-\mathrm{X}$ feature variance,

$S_{Y}^{2}-Y$ feature variance,

$S_{X}-\mathrm{X}$ feature standard deviation,

$S_{Y}$ - Y feature standard deviation.

The linear correlation coefficient can be treated as normalized covariance. Correlation always takes values in the range $(-1,1)$.

\section{Research results and discussion}

The factor determining milk production in a direct way is the sheep population, and especially the population of ewes used for milk. In the years 2008-2017, the total sheep population in the EU countries fell from 90.7 million pieces to 86.8 million pieces. At the same time, the population of sheep used for milk production remained at a similar level of around $25-26$ million pieces, i.e. it accounted for $28-29 \%$ of the entire sheep population (Figure 1). In the years 2008-2017, the production of milk intended for processing in dairies increased by $21 \%$, although in the initial years of this period there were even drops. The presented data suggest that less milk was spent on internal consumption of farms and more on processing in dairies. In the years 2008-2017, the production of cheese increased by $48 \%$ from 157 thousand tons up to 232 thousand tons.

Commodity production of sheep's milk was concentrated in countries with the largest stock of milk ewes, i.e. in Greece, Spain, Italy and France. The smallest production occurred in countries with small sheep populations and maintaining meat breeds. In 2008-2017, there were changes in the production of sheep's 
milk in particular countries. Table 1 presents the dynamics of changes in sheep milk production in individual EU countries. The changes were shown using chain indexes, where the previous year was accepted as 100. The countries were ranked in descending order according to the production volume of sheep's milk. Changes in individual countries varied. After a period of decline, the increase was most often recorded in subsequent years. The biggest decreases in the leading producers of sheep's milk were recorded in 2011 and 2017, while the largest increases in 2014-2016. It may seem that the production of sheep's milk has little to do with the economic situation. In 2008-2017, the highest increase in sheep milk production was recorded in Bulgaria (by $61 \%$ ) and Austria (by $25 \%$ ). However, these were countries with a small scale of production. Among the leading producers of sheep milk, only a small increase was recorded in Greece (by $7 \%$ ). In other countries there was stagnation or declines.

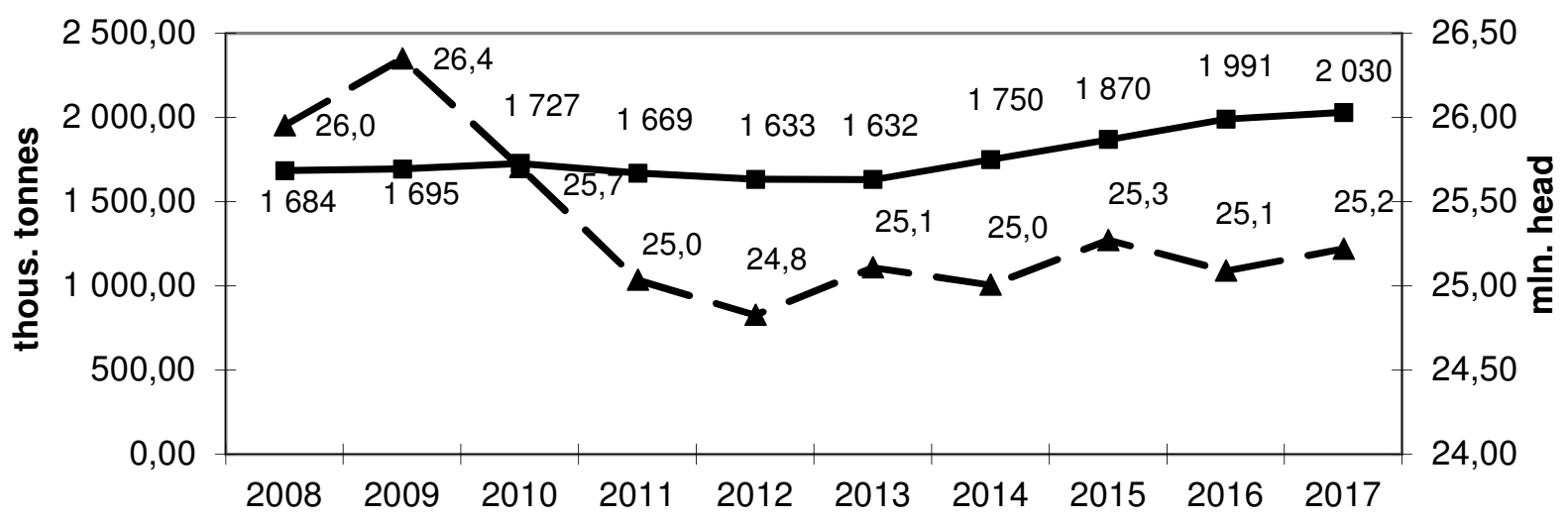

$\rightarrow$ commercial production of sheep's milk $\rightarrow$ - population of dairy sheep

years

Source: authors' elaboration

Fig. 1. Population of dairy sheep and commercial production of sheep's milk in the EU in 2008-2017

Table 1

The dynamics of changes in commercial production of sheep's milk in individual EU countries in 2008-2017 (previous year $=100$ )

\begin{tabular}{|c|c|c|c|c|c|c|c|c|c|c|}
\hline \multirow{2}{*}{ Countries } & \multicolumn{10}{|c|}{ Changes in commercial production of sheep's milk in years } \\
\hline & 2008 & 2009 & 2010 & 2011 & 2012 & 2013 & 2014 & 2015 & 2016 & 2017 \\
\hline Greece & 100.0 & 106.8 & 97.2 & 90.9 & 101.4 & 109.4 & 99.4 & 97.5 & 109.0 & 97.1 \\
\hline Spain & 100.0 & 99.6 & 101.6 & 96.4 & 101.1 & 102.8 & 122.3 & 95.1 & 85.1 & 95.1 \\
\hline Italy & 100.0 & 92.0 & 106.7 & 99.0 & 99.8 & 97.6 & 102.7 & 109.9 & 100.2 & 94.1 \\
\hline France & 100.0 & 102.4 & 103.3 & 96.7 & 96.9 & 98.3 & 103.8 & 100.7 & 105.8 & 93.4 \\
\hline Bulgaria & 100.0 & 115.1 & 78.6 & 85.9 & 138.6 & 92.2 & 104.7 & 72.2 & 153.5 & 139.9 \\
\hline Cyprus & 100.0 & 131.3 & 71.9 & 107.6 & 96.1 & 92.6 & 149.2 & 78.9 & 115.0 & 91.4 \\
\hline Romania & 100.0 & 100.7 & 118.6 & 73.2 & 125.6 & 104.7 & 130.9 & 72.3 & 101.5 & 82.3 \\
\hline Portugal & 100.0 & 96.2 & 114.5 & 84.2 & 120.8 & 89.0 & 99.0 & 111.8 & 97.2 & 93.5 \\
\hline Slovakia & 100.0 & 99.1 & 117.0 & 78.9 & 114.7 & 105.8 & 116.9 & 69.7 & 119.1 & 89.5 \\
\hline Austria & 100.0 & 116.8 & 93.1 & 96.9 & 115.1 & 80.2 & 93.9 & 139.8 & 68.1 & 144.1 \\
\hline Croatia & 100.0 & 288.4 & 35.2 & 98.9 & 104.6 & 88.4 & 120.0 & 83.5 & 118.1 & 83.0 \\
\hline Hungary & 100.0 & 112.5 & 101.2 & 72.8 & 122.4 & 54.3 & 186.4 & 112.4 & 104.0 & 98.8 \\
\hline Poland & 100.0 & 142.9 & 28.0 & 875.0 & 28.6 & 92.9 & 165.7 & 100.8 & 68.7 & 93.9 \\
\hline Belgium & 100.0 & 200.0 & 75.0 & 66.7 & 100.0 & 66.7 & 150.0 & 700.0 & 14.3 & 100.0 \\
\hline
\end{tabular}

Source: authors' elaboration

The Gini coefficient was used to determine the concentration of sheep milk production in EU countries. The data concerned the years 2008 and 2017, and the number of observations was 14. In 2008, the Gini coefficient calculated from the sample was 0.72 , and the estimated coefficient for the population 0.78 . This 
means a very high concentration of sheep's milk production and diversity in EU countries. In addition, these differences are presented in the Lorenz concentration curve (Figure 2). In 2017, Gini coefficients were at a similar level as in 2008 (from the 0.71 sample, estimated at 0.77 ). This means that the high concentration of sheep milk production has been maintained and No changes occurred.
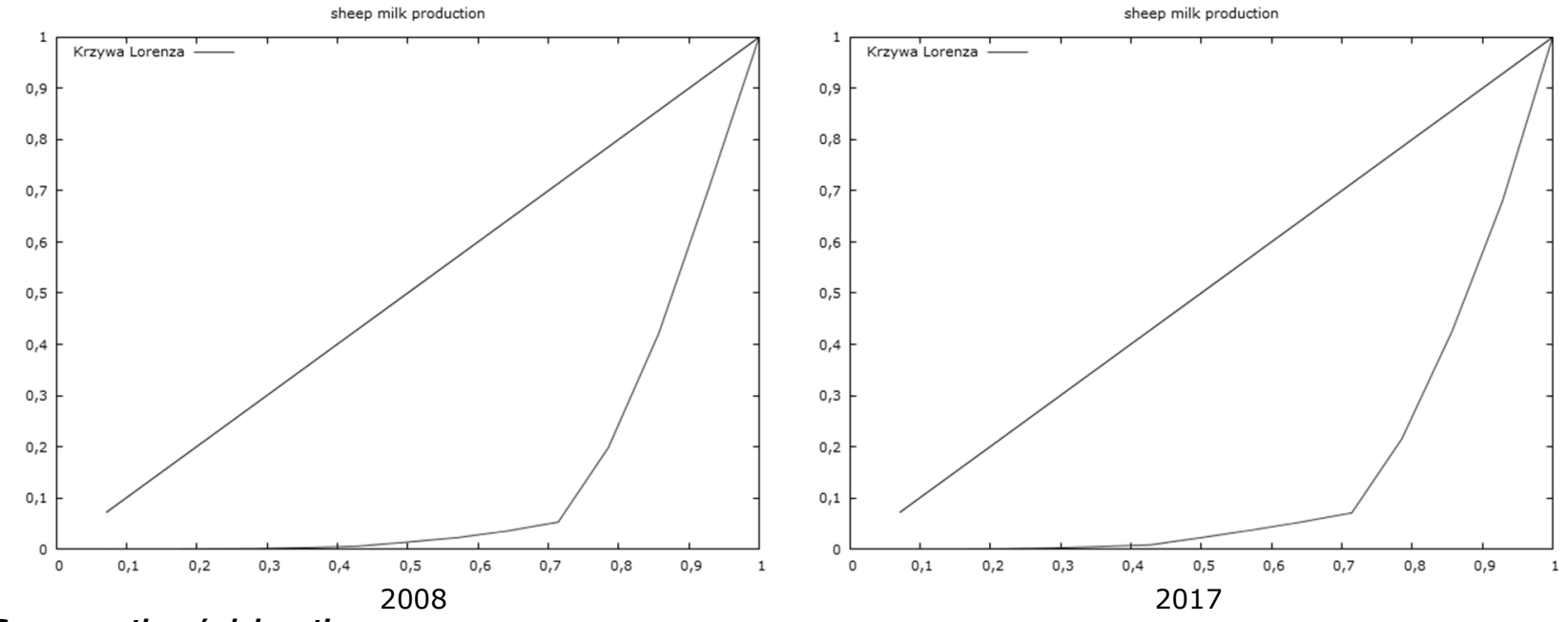

Source: authors' elaboration

Fig. 2. Lorenz concentration curve for the commercial production of sheep's milk in the EU countries in 2008 and 2017

Pearson correlation coefficients between commercial production of sheep's milk in top 14 EU countries and selected parameters in 2008-2017

\begin{tabular}{|c|c|c|c|c|c|c|c|c|c|c|c|}
\hline \multirow[b]{2}{*}{ Parameters } & \multicolumn{11}{|c|}{ Pearson linear correlation coefficients in years } \\
\hline & 2008 & 2009 & 2010 & 2011 & 2012 & & & & 16 & 2017 & $\begin{array}{l}2008- \\
2017\end{array}$ \\
\hline \multicolumn{12}{|c|}{ n between commercial production of sheep's milk and } \\
\hline Value of GDP & 0.649 & 0.620 & 0.605 & 0.614 & 0.611 & 0.571 & 0.5 & 34 & 48 & 522 & 0.501 \\
\hline $\mathrm{p} v a$ & 0.012 & 0.018 & 0.022 & 0.019 & 0.020 & 0.033 & 0.042 & .040 & 0.042 & 0.056 & 0.001 \\
\hline \multirow{2}{*}{$\begin{array}{l}\text { GDP per capita } \\
\text { p value }\end{array}$} & & & & & & & & & & & 0.256 \\
\hline & & & & & & & & & & & 02 \\
\hline $\begin{array}{l}\text { Household consumption } \\
\text { per capita }\end{array}$ & & 0. & & & & & & & 285 & 262 & (5) \\
\hline$p$ value & 0.092 & 0.094 & 0.120 & 0.155 & 0.209 & 0.261 & 0.299 & 0.300 & 0.323 & 0.366 & 0.001 \\
\hline \multirow{2}{*}{$\begin{array}{l}\text { Value of export } \\
p \text { value }\end{array}$} & 18 & 0.475 & 0.465 & 0.485 & 0.494 & 0.463 & 0.446 & 0.453 & 0.438 & 0.413 & 0.460 \\
\hline & 0.058 & 0.086 & 0.094 & 0.079 & 0.073 & 0.096 & 0.110 & 0.104 & 0.117 & 0.142 & 0.001 \\
\hline \multirow{2}{*}{$\begin{array}{l}\text { Value of import } \\
p \text { value }\end{array}$} & 0 & 0.515 & 0.503 & 0.504 & 0.490 & 0.447 & 0.427 & 434 & 415 & 0.393 & 0.462 \\
\hline & 0.0 & 0.060 & 0.067 & 0.066 & 0.076 & 0.109 & 0.127 & 0.121 & 140 & .164 & .001 \\
\hline \multirow{2}{*}{$\begin{array}{l}\text { Sheep population total } \\
\mathrm{p} \text { value }\end{array}$} & & 36 & & & 77 & & & & 08 & 77 & .776 \\
\hline & 0.002 & 0.003 & 0.001 & 0.001 & 0.001 & 0.001 & 0.001 & 0.001 & 0.001 & 0.001 & 0.001 \\
\hline \multirow{2}{*}{$\begin{array}{l}\text { Sheep milk population } \\
\mathrm{p} \text { value }\end{array}$} & 0.690 & 0.686 & 0.716 & 0.684 & 0.663 & 0.656 & 0.615 & 0.594 & 0.597 & 0.609 & 0.646 \\
\hline & 0.006 & 0.007 & 0.004 & 0.007 & 0.010 & 0.011 & 0.019 & 0.025 & 0.024 & 0.021 & 0.001 \\
\hline \multirow{2}{*}{$\begin{array}{l}\text { Sheep meat production } \\
\mathrm{p} \text { value }\end{array}$} & 0.699 & 0.714 & 0.730 & 0.688 & 0.680 & 0.649 & 0.684 & 0.697 & 0.688 & 0.647 & 0.678 \\
\hline & 0.005 & 0.004 & 0.003 & 0.007 & 0.007 & 0.012 & 0.007 & 0.006 & 0.007 & 0.012 & 0.001 \\
\hline
\end{tabular}

Source: authors' elaboration

In order to establish the relationship between the production volume of sheep's milk in the European Union countries and the basic parameters of sheep production and the economy, Pearson's linear correlation coefficients were calculated (Table 2). The $p=0.05$ was assumed as the threshold of significance level. Significant results have been marked with a grey background in the table. Correlation coefficients have been calculated for EU countries in individual years as well as in the entire period 2008-2017. The paper 
tried to check the correlation, which does not indicate that a given factor affects another, only that there is a strong or weak relationship between them.

Significant average positive relationships between the production volume of sheep's milk and the GDP value were found. These dependencies gradually weakened in subsequent years. In the case of other parameters of the economy, No significant dependence was found on the production volume of sheep's milk. There was also a very high positive relationship between the production of sheep's milk and the parameters related to sheep production, such as sheep stock, dairy sheep population, and production of lamb meat. Of these parameters, the impact of the population of dairy sheep was the smallest.

Products of dairy sheep are very much linked to historical and cultural uniqueness right through the production, marketing and consumption chains (Boyazoglu and Morand-Fehr, 2001). According to Haenlein (2007) and Astruc et al. (2002), higher milk production may be due to genetic selection of animal and better nutrition conditions. Some sheep breeds can produce more than $1000 \mathrm{~kg}$ milk in one lactation. Sheep feeding also affects the quality of milk determined by the content of food ingredients, such fat, protein etc. (Pulina et al., 2005). In recent years, several traits linked with functional longevity of dairy sheep's (udder morphology, somatic cell count, etc.) are taking on a more important role (Ugarte and Gabina, 2004). Very important is lamb production, which accounts for a substantial part of income for dairy sheep farmers, e.g. 25 to $35 \%$ in Slovakia, 30 to $60 \%$ in the Mediterranean countries (Krupova et al., 2009; Rokicki, 2015).

\section{Conclusions}

1) Based on the empirical studies presented in the work, some generalisations and conclusions have been formulated. In 2008-2017, the production of sheep's milk intended for processing in dairies increased, which might have been a result from the less internal consumption of farms. Among the leading producers of sheep milk, only a small increase was recorded in Greece. In other countries there was stagnation or declines. In particular years there were declines and increases in production, which may have been caused by more or less favourable climatic conditions occurring in the given years.

2) The first hypothesis was rejected. In 2008-2017, the level of concentration of sheep milk production in the EU was very high, but there were No changes in this regard. Commercial production of sheep's milk was concentred in several countries, like Greece, Spain, Italy and France. Second hypothesis assumed, that commercial production of sheep's milk was more correlated with the population of dairy sheep than with other parameters related to sheep production. This hypothesis was rejected, too. For all the parameters, correlations were very high, but sheep population and lamb meat production were correlated more with milk production.

\section{Bibliography}

1. Al-Wabel, N.A. (2008). Mineral Contents of Milk of Cattle, Camels, Goats and Sheep in the Central Region of Saudi Arabia. Asian Journal of Biochemistry, 3(6), pp. 373-375.

2. Astruc, J.M., Barillet, F., Barbat, A., Clement, V., Boichard, D. (2002). Genetic Evaluation of Dairy Sheep in France. 7th World Congress on Genetics Applied to Livestock Production, Montpellier, France, pp. 231-234.

3. Barlowska, J., Szwajkowska, M., Litwinczuk, Z., Krol, J. (2011). Nutritional Value and Technological Suitability of Milk from Various Animal Species Used for Dairy Production. Comprehensive Reviews in Food Science and Food Safety, 10(6), pp. 291-302.

4. Bawa, S. (2003). An Update on the Beneficial Role of Conjugated Linoleic Acid (CLA) in Modulating Human Health: Mechanisms of Action-a Review. Polish Journal of Food and Nutrition Sciences, 12(3), pp. 3-13.

5. Boyazoglu, J., Morand-Fehr, P. (2001). Mediterranean Dairy Sheep and Goat Products and Their Quality: A Critical Review. Small Ruminant Research, 40(1), pp. 1-11.

6. Dagum, C. (1980). The Generation and Distribution of Income, the Lorenz Curve and the Gini Ratio. Economie Appliquée, 33, pp. 327-367.

7. Damgaard, C., Weiner, J. (2000). Describing Inequality in Plant Size or Fecundity. Ecology, 81, pp. 1139-1142.

8. Dankow, R., Pikul, J. (2011). Przydatność technologiczna mleka owczego do przetwórstwa (Technological Suitability of Sheep Milk for Processing). Nauka Przyroda Technologie, 5(2), pp. 7. 
9. Dario, C., Carnicella, D., Dario, M., Bufano, G. (2008). Genetic Polymorphism of $\beta$-lactoglobulin Gene and Effect on Milk Composition in Leccese Sheep. Small Ruminant Research, 74(1-3), pp. 270-273.

10. de la Fuente, M.A., Mercedes, R., Isidra, R., Manuela, J. (2013). Sheep Milk. Milk and Dairy Products in Human Nutrition: Production, Composition and Health, Park Y.W., Haenlein G.F.W. (ed.), John Wiley \& Sons Ltd., New York, pp. 554-577.

11. Dixon, P.M., Weiner, J., Mitchell-Olds, T., Woodley, R. (1988). Erratum to Bootstrapping the Gini Coefficient of Inequality. Ecology, 69, p. 1307.

12. Faostat (2017). Sheep Milk, Whole, Fresh. Retrieved: http://www.fao.org/faostat/en/\#data/QL Access: 30.01.2019.

13. Gavino, V.C., Gavino, G., Leblanc, M.J., Tuchweber, B. (2000). An Isomeric Mixture of Conjugated Linoleic Acids but not Pure cis-9, trans-11-octadecadienoic Acid Affects Body Weight Gain and Plasma Lipids in Hamsters. The Journal of Nutrition, 130(1), pp. 27-29.

14. Haenlein, G.F.W. (2007). About the Evolution of Goat and Sheep Milk Production. Small Ruminant Research, 68(12), pp. 3-6.

15. Jajuga, K., Walesiak, M. (2004). Remarks on the Dependence Measures and the Distance Measures. In: Klasyfikacja i analiza danych - teoria i zastosowania, Prace Naukowe Akademii Ekonomicznej we Wrocławiu nr 1022, AE, Wrocław, pp. 348-354.

16. Krupova, Z., Wolfova, M., Wolf, J., Oravcova, M., Margetin, M., Peškovicova, D., Krupa E., Dano, J. (2009). Economic Values for Dairy Sheep Breeds in Slovakia. Asian Australasian Journal of Animal Science, 22, pp. 16931702.

17. Milk and Milk Product Statistics (2017). Eurostat Statistical Explained. Retrieved: https://ec.europa.eu/eurostat/ statistics-explained/index.php/Milk_and_milk_product_statistics Access: 30.12.2018.

18. O'shea, M., Bassaganya-Riera, J., Mohede, I.C. (2004). Immunomodulatory Properties of Conjugated Linoleic Acid. The American Journal of Clinical Nutrition, 79(6), pp. 1199-1206.

19. Park, Y.W., Juarez, M., Ramos, M., Haenlein, G.F.W. (2007). Physico-chemical Characteristics of Goat and Sheep Milk. Small Ruminant Research, 68(1-2), pp. 88-113.

20. Parodi, P.W. (1999). Conjugated Linoleic Acid and Other Anticarcinogenic Agents of Bovine Milk Fat. Journal of Dairy Science, 82(6), pp. 1339-1349.

21. Pulina, G., Macciotta, N., Nudda, A. (2005). Milk Composition and Feeding in the Italian Dairy Sheep. Italian Journal of Animal Science, 4(sup1), pp. 5-14.

22. Rokicki, T., (2015). Economic Results of Sheep Farms in Poland, Economic Science for Rural Development, Economic Science for Rural Development. Proceedings of the International Scientific Conference, No 37, pp. 86-92.

23. Rokicki T., (2017). Food security in the European Union - case study of lamb market, Economic Science for Rural Development, Economic Science for Rural Development. Proceedings of the International Scientific Conference No 45, pp. 344-350.

24. Rokicki T., Ratajczak M., 2018: Segmentation of the EU countries in terms of the sheep production, Economic Science for Rural Development, Economic Science for Rural Development. Proceedings of the International Scientific Conference, No 48, pp. 229-236.

25. Sinanoglou, V.J., Koutsouli, P., Fotakis, C., Sotiropoulou, G., Cavouras, D., Bizelis, I. (2015). Assessment of Lactation Stage and Breed Effect on Sheep Milk Fatty Acid Profile and Lipid Quality Indices. Dairy Science \& Technology, 95(4), pp. 509-531.

26.Starzynska, W. (2002). Statystyka praktyczna (Practical Statistics), Wydawnictwo Naukowe PWN, Warszawa, p. 102.

27.Talpur, F.N., Bhanger, M.I., Khooharo, A.A., Memon, G.Z. (2008). Seasonal Variation in Fatty Acid Composition of Milk from Ruminants Reared under the Traditional Feeding System of Sindh, Pakistan. Livestock Science, 118(1-2), pp. 166-172.

28. The Sheep and Goat Sector in the EU. Main Features, Challenges and Prospects (2017). Briefing September 2017, European Parliament, Brussels.

29. Tricon, S., Burdge, G.C., Kew, S., Banerjee, T., Russell, J.J., Jones, E.L., Calder, P.C. (2004). Opposing Effects of cis-9, trans-11 and trans-10, cis-12 Conjugated Linoleic Acid on Blood Lipids in Healthy Humans. The American Journal of Clinical Nutrition, 80(3), pp. 614-620.

30. Ugarte, E., Gabina, D. (2004). Recent Developments in Dairy Sheep Breeding. Archiv fur Tierzucht, 47(6; SPI), pp. 10-17.

31. Wang, Y., Jones, P.J. (2004). Dietary Conjugated Lnoleic Acid and Body Composition. The American Journal of Clinical Nutrition, 79(6), pp. 1153-1158.

32. Watkins, B.A., Seifert, M. F. (2000). Conjugated Linoleic Acid and Bone Biology. Journal of the American College of Nutrition, 19(4), pp. 4785-4865. 